\title{
How do teachers collaborate in Hungarian VET schools? A quantitative study of forms, perceptions of impact and related individual and organisational factors
}

\author{
Eszter Bükki ${ }^{1^{*}}$ (D) and Anikó Fehérvári ${ }^{2}$ (D)
}

\author{
*Correspondence: \\ bukki.eszter@ppk.elte.hu \\ ${ }^{1}$ Doctoral School \\ of Education, Institute \\ of Education, ELTE Eötvös \\ Loránd Tudományegyetem, \\ Budapest, Hungary \\ Full list of author information \\ is available at the end of the \\ article
}

\begin{abstract}
Background: This study investigates teacher collaboration in Hungarian vocational education and training (VET) schools based on an online survey of teachers $(n=303)$. Collaboration of teachers has long been appreciated for its significant benefits including increased motivation, job satisfaction, self- and collective efficacy, as well as its role in teacher professional development and school improvement. Collaboration of teachers working in VET schools, especially in VET systems where initial VET is provided to young people and (in part) within compulsory education, appears as particularly desirable, given the special context, objectives and challenges of this sector and the spread of competence-based education. However, relatively little is known about VET teacher collaboration, especially in Hungary, where three different profiles of teachers-general subject and vocational teachers and vocational trainers-work in VET schools. The aim of our study was to provide data about how Hungarian VET teachers collaborate, which could validate prior research results on teacher collaboration as well as identify any special features of the VET context.
\end{abstract}

Method: Our study design was exploratory, descriptive and correlational, applying quantitative statistical analysis. We measured teacher collaboration (practice and perception of impact) and explanatory individual and organisational factors selected for our research framework by adapting instruments of previous empirical studies (most importantly, OECD's TALIS). We analysed connections between collaboration and independent variables created by principal component analysis.

Results: Our data show that sharing-type collaboration (professional discussions and exchange of materials) are widespread among Hungarian VET teachers. They are much less likely to participate in deeper collaborative activities that presuppose higher levels of interdependence, and they also appreciate the impact of deeper collaboration less. Female respondents participate in sharing-type activities more than their male colleagues, and middle-aged (40-55) are most active in both types of collaboration and perceive the most impact. Collaboration practices correlate most with perceptions of their impact. More frequent collaboration and perceptions of higher impact are related to teachers'sense of higher self-efficacy and relaxed, tolerant and encouraging collegial relationships. Structural barriers seem to influence only sharing and perceptions 
of impact. Small, but statistically significant differences in collaboration were found between the three teacher profiles. Vocational trainers (who instruct vocational school practice) showed the highest level of participation in deeper collaboration, while vocational teachers were least likely to participate and perceived the least impact. No significant associations were found between collaboration and prior or current work experience in the taught vocation.

Conclusions: Our results largely confirm and validate previous research on teacher collaboration in lower level and general educational contexts by providing data on VET teacher collaboration. They also note the role of some VET-specific factors, such as structural barriers and small, but statistically significant differences between different VET teacher profiles.

Keywords: Vocational education and training, Teacher collaboration, Collegiality, Teacher professional development and learning, Teacher survey

\section{Introduction}

Although the work of teachers is traditionally characterized by high levels of individualism and isolation (Lortie 1975; Rosenholtz 1989), collaboration among teachers has been increasingly advocated in the past decades (Goddard et al. 2007). Significant benefits were contributed to teacher collaboration, ranging from increased teacher motivation, morale, job satisfaction, commitment, enthusiasm, self- and collective efficacy to improved communication and school climate supportive of innovation (Leana 2011; Hargreaves and Fullan, 2012; Vangrieken et al. 2015; Ainley and Carstens 2018). Studies found that the collaboration of teachers can significantly foster their professional learning and, through that, improve student achievement (Bolam et al. 2005; Goddard et al. 2007; Reeves et al. 2017).

Most research on teacher collaboration, however, were conducted in schools within the sectors of primary and secondary general education. Studies on collaboration within institutions that provide vocational education and training (VET) are rather scarce. Indeed, VET is a very heterogeneous sector and many potentially relevant factors that may enhance, or hinder teacher collaboration relate to features of national VET systems. These include the level of education where VET is provided (upper or post-secondary, within compulsory or further education), the content and organization of VET (share and role of school-based general and vocational education, and form of collaboration with in-company trainers), and, related to these, the different types or 'profiles' of VET teachers with divergent qualification requirements and professional background (Cedefop 2017; Misra 2011).

Nevertheless, a common feature across VET systems is that teachers of vocational subjects are described as 'dual professionals'. That implies that they are expected to maintain current vocational competencies as well as pedagogical skills for effective VET teaching practice (Schmidt 2019). However, often, the former seems to be prioritised (Cedefop 2016; Köpsén and Andersson 2017). Strengthening cooperation between VET institutions and labour market actors to ensure the quality and relevance of VET is high on the policy agenda in many countries. Enhancing professional learning and improving VET quality through promoting teacher collaboration within VET institutions appears to be a much less widespread policy objective. This may be all the more surprising considering that competence-based education has become increasingly dominant in many VET 
systems. Competence-based VET aims to provide students with authentic integrated knowledge, skills and attitudes required to perform a vocation, its implementation would therefore naturally call for the intense cooperation of VET teachers (De Bruijn 2012; Nissilä et al. 2015). Indeed, in Dutch VET schools, multidisciplinary teacher teams are held responsible for the design and execution of programmes for specific vocations (Brouwer et al. 2016).

Although competence-based VET has long been advocated in Hungary, no specific measures were introduced to improve teacher collaboration within VET schools. In fact, hardly any research-based data are available on how Hungarian VET teacherswho include teachers of general subjects, teachers of vocational theorical subjects, and trainers supervising in-school VET practice-collaborate. The objective of our study was therefore to explore the forms of teacher collaboration in Hungarian VET schools, and the influence of some general and VET-specific factors, based on a quantitative analysis of data collected in an online survey of VET teachers $(n=302)$ in one vocational centre.

\section{Theoretical background}

"Teacher collaboration" is a widespread term, but, as Kelchtermans (2006) noted in his literature review, it is not an unambiguous concept. Kelchtermans defined it as a descriptive term referring to teachers' cooperative actions (their actual doing things together) for job-related purposes. He distinguished it from the term "collegiality", which refers to the quality of relationships among staff members, i.e., an aspect of the school's organisational culture, which implies a normative dimension. Nevertheless, collaboration and collegiality are considered as constituting and reflecting each other in an ongoing process. Drawing on earlier research, Kelchtermans (2006) argued that in order to properly understand their meaning and impact, it is important (1) to differentiate between different forms of teacher collaboration, (2) to appreciate the value of both collaboration and autonomy, and also (3) to take into account the content or agenda of collaboration.

As early as 1990, Little urged paying attention to both the variable forms and content (defined as "the collectively held beliefs, ideas and intentions") of "collegial relations", as these may lead to very different consequences: conserving the present or promoting change (Little 1990). She distinguished four "ideal types" of collegiality that reflect increasing degrees of interdependence among teachers, and thus "present changes in the frequency and intensity of teachers' interactions, the prospects for conflict, and probability of mutual influence": "Storytelling and Scanning for ideas", "Aid and Assistance"; "Sharing" and "Joint work". In their literature review, Vangrieken et al. (2015) suggested conceptualizing different forms of teacher collaboration as being at some place on a continuum, depending on the degree to which they meet their criteria of "team entativity": shared goals and responsibilities, task cohesion (commitment), identification, task and outcome interdependence.

Vangrieken et al. (2015) summarized the various personal, structural, group, process and organisational factors that previous studies had found to facilitate or hinder teacher collaboration, sometimes in a curvilinear relationship. Personal factors include willingness or commitment to collaborate, understanding the benefits of teaming, and the combination of particular skills, knowledge and experience in teaming. The most important structural factors relate to time issues, staff continuity, physical proximity and 
formalisation/regulation of professional interaction. Group and process characteristics (that is, features specific to the particular team and their working together) had the largest share of facilitators, including team size, supportive atmosphere, transformational leadership, and flexibility, task emphasis, interdependence, among others. Influencing factors of the larger context (the organisation) relate to cultural issues, trust, monitoring, governance structures and leadership.

Deep level teacher collaboration is rather rare, due to various sources of resistance in teacher culture (teachers tend to avoid conflict and preserve their norms of privacy and autonomy) and certain structural characteristics (such as school size, time issues, staff continuity, physical structures, etc., Vangrieken et al. 2015). As Kelchtermans (2006) put it, the cultural and structural working conditions in a school determine and mediate actual teacher collaboration, as well as the way collegiality is experienced and valued. Some studies furthermore suggest that the learning potential of teacher collaboration and collegiality as workplace conditions ultimately depend on personal characteristics. Attitudes, motivation or the perception of feasibility or meaningfulness mediate the effects of job and organisational factors (Kwakman 2003). Hoekstra et al. (2009) argued that the relationship between collaboration (defined as the level of interdependency between teachers) and learning, or between shared norms and learning, depend on how this collaboration or the (lack of) shared norms are interpreted and shaped by the individual teacher. That is, the conditions for informal learning in the work environment are partially shaped by the availability of resources and general conditions in the school, and partially by the teachers as actors and active interpreters of their work (echoing Billet's principle of "dual participation", Billett 2004; cf. also Hodkinson and Hodkinson 2005 and Opfer and Pedder 2011).

Quantitative studies of teachers' workplace learning also highlighted the significant role of psychological factors. In particular, they found that teachers' sense of self-efficacy was the most important motivational factor, which also mediated the impact of teamwork processes and other organisational factors (Geijsel et al. 2009, Thoonen et al. 2011). Based on Bandura's (1997) original concept, teacher self-efficacy refers to teachers' beliefs about their own ability to to enact certain teaching behaviour that influences students' educational outcomes (Tschannen-Moran and Hoy 2001). Self-efficacy strengthens teachers in pursuing interests through setting themselves challenges, and it also takes away fear of failure and thus strengthens persistence in pursuing goals (Beverborg et al. 2015).

Collaboration is conceptualized as a type of teachers' "professional practices" in OECD's Teaching and Learning international Survey (TALIS). It distinguishes "exchange and cooperation" from "professional collaboration", which imply a deeper level of cooperation and more interdependence between teachers (such as co-teaching, engaging in joint activities, or observing colleagues' classes and giving feedback). According to the results of the latest TALIS 2018 survey, and in line with previous TALIS findings, large proportions of teachers report never engaging in these deeper forms of collaboration (OECD 2020). Some of the variation of teacher collaboration in TALIS data are explained at the country level (by cultural and contextual factors), but most of the variance is at the individual level, though the share of variation lying at the school level is not negligible either. Male teachers tend to engage more often in deeper forms of collaboration, 
and there is a significant negative association between age and engagement in professional collaboration in around one-fourth of the countries. However, teachers with more years of experience tend to collaborate more frequently than teachers of the same age but with fewer years of experience. The data confirm the importance of a sense of collegiality (positive interpersonal relationships) and distributed leadership for boosting collaboration.

TALIS survey findings suggest that collegiality decreases with higher levels of education. Teachers in upper secondary education appear to work less collaboratively and more in isolation than their primary and lower secondary counterparts (OECD 2020). In spite of several major differences between primary and secondary schools (e.g. size, student age, class size, teacher specialization or pre-service education), Timperley et al. (2007) found no significant differences between these sectors regarding the conditions of effective teacher professional learning-except for one. There is one feature unique to secondary schools, which does exert enormous influence on teacher learning: the way schools are organised into subject-based departments, often resulting in balkanized school cultures (Hargreaves 1994; see also Hodkinson and Hodkinson 2005).

Available evidence suggests that the prevailing model in VET teacher communities is similarly individualistic, discipline-divided and course/department-based, and deep level collaboration is rather rare. A Finnish qualitative study has found that obstacles of collaboration refer to teachers' self-image, low self-esteem and a deeply rooted fear of criticism or revelation of incompetence, while promoters of cooperation were connected to the changing practices and desire of sharing with colleagues (Nissilä et al. 2015). Nevertheless, interaction with peers is an important and appreciated form of VET educator learning. A Swiss qualitative study of VET teachers found that "sharing", meaning any type of exchange such as discussions with a role model or exchanges with peers, were important triggers of change. They had the strongest impact on the evolution of teachers' practices compared with the other two triggers of teacher education and teaching experience (Girardet and Berger 2017).

In many countries, teachers of vocational subjects are typically hired from among professionals in the field and had not received (pre-service) teacher education. Most of their formal professional development opportunities also focus on content knowledge, maintaining industry currency. Therefore, they rely on each other, trial-and-error, student feedback, and peer feedback to develop their pedagogical content knowledge (Hoekstra et al. 2015; Hoekstra and Newton 2017; Tyler and Dymock, 2019). Hoekstra and Pederson (2018) also found that instructors in the different departments of Canadian VET institutions had specific ways of working together. The authors argued that these were related to the specific values, principles and logic of their original profession/trade.

\section{Present study: context and research questions}

The present analysis was prepared as part of a $\mathrm{PhD}$ project exploring individual and organisational factors that may facilitate or hinder teacher professional learning in Hungarian VET schools. Initial VET in Hungary is (currently) provided to students from age 14 in three programme types (Bükki 2019):

(1) Vocational programmes for learners with special education needs (SEN); 
(2) Three-year upper secondary level skilled workers' training, which involves general education in one third of their curricula, with around $60 \%$ of students holding an apprenticeship contract (followed by an optional two-year general education programme to obtain the secondary school certificate);

(3) Highest-prestige VET programmes that combine general and vocational education at upper secondary level (first four years), followed by one-year post-secondary VET, with only a fourth of students holding an apprenticeship contract; two-year post-secondary VET is also available to those with the secondary school certificate but no prior vocational training.

Since general education and in-school vocational practice are included in the curriculum of each programme type, three different profiles of teachers work in Hungarian VET schools: teachers of general (academic) subjects, vocational teachers who teach vocational subjects (mainly theory), and vocational trainers who supervise vocational practice in school workshops. These teacher profiles are characterised by different qualification requirements and professional background. While a subject-relevant master level teacher qualification is required from both general subject and vocational teachers, vocational trainers can be employed with a bachelor level "vocational instructor" qualification, or even with only a secondary school certificate, a relevant vocational qualification and at least five years of professional experience. Expert interviews and a previous study suggest that a substantial proportion of vocational teachers and trainers are second-career teachers also in Hungary, who start their "pre-service" teacher education only after they had started teaching (Bükki 2018). However, due to the unattractive working conditions (low salary, low prestige, decreasing teacher autonomy and highly challenging job), it is getting increasingly difficult to hire vocational teachers/trainers. The VET teacher population is aging, and the share of part-time instructors is growing (Információs és Technológiai Minisztérium 2018).

In spite of several major reforms in the past decades, the prestige and attractiveness of VET in Hungary is low compared to general education. Especially the lower-level VET programmes attract mostly low-achieving students, often from disadvantaged social background, with poor basic skills and motivations. Dropout rates are high, and student achievement (in terms literacy and maths competences) is very low in many VET schools (Fehérvári 2014; Hermann et al. 2016).

While the curricula and organisation of VET, its current challenges and the policy objective of implementing competence-based VET (Bükki 2018) would naturally call for the intensive collaboration of VET teachers, no specific measures were introduced to promote this. In fact, hardly any research data are available on how teachers collaborate in Hungarian VET schools and what specific factors may facilitate or hinder that. Some qualitative studies suggest that many VET schools have strong, collegial professional communities, often strengthened by a sense of mutual interdependence due to the near-permanent VET reforms, and the need for continuous renewal (Expanzió Humán Tanácsadó 2015). Some common structural and cultural features of VET schools, such as physical separation and different time schedules, or sometimes even a sense of conflict between general and vocational teachers, may, however, significantly limit teacher collaboration. 
Our study therefore aimed to provide answers to these research questions:

- In what forms do teachers collaborate in Hungarian VET schools, how do they perceive the impact of different forms of collaboration for their own professional development, and what barriers to collaboration do they perceive?

- How are their collaboration practices and perceptions of impact related to selected general and VET-specific individual and organisational characteristics?

Based on the literature, we hypothesized that the following VET-specific individual factors and structural and cultural conditions of the organisational context might be relevant to better understand teacher collaboration in Hungarian VET:

- different VET teacher profiles imply different qualifications, professional background, and work contexts, which might be associated with individual (motivation, beliefs) as well as cultural factors (collegiality) that influence collaboration practices and perceptions of impact;

- structural features of the organisational context, related to human resources (such as high share of part-time instructors or frequent change of staff) and the organization of work (such as time scheduling, physical space, or arrangements for and nature of formal collaboration), may hinder the collaboration of VET teachers.

\section{Methods}

Our study design was exploratory, descriptive and correlational, applying quantitative statistical analysis.

\section{Sample}

Data were collected in an online survey in 2019 among VET teachers working in one vocational centre in the capital city. Five of the eleven member schools of this centre provided only the highest prestige VET programmes, the rest mixed types of programmes. Teachers were contacted through their principals. The final sample size is 303 , after excluding cases with a high share of missing data. Response rate was $46.4 \%$ compared to all teachers working in the vocational centre, and $54.2 \%$ compared to those who worked (full- or part-time) with an employment contract.

The majority (54.5\%) of respondents were general subject teachers, one third $(29 \%)$ vocational teachers and one sixth $(16.5 \%)$ vocational trainers (see Table 11 in appendix). The programme offer of this vocational centre is highly heterogeneous. Most (more than one third) of our respondents teach students for jobs in the trades, nearly one third in the services or in sports, one fifth in arts and dressmaking/leathercraft, and the rest in commerce, administration, catering and agriculture. 


\section{Instruments}

The variables used in this analysis were selected from our longer questionnaire on VET teacher professional learning and development.

\section{Teacher collaboration}

We measured collaboration practices by adapting the teacher collaboration scale of OECD's TALIS 2018 questionnaire, including some items from Opfer et al. (2011) and Geijsel et al. 2009). Teachers were asked to indicate on a scale of 1 to 4 how typical it was for them to do these activities.

For each collaborative activity, we also asked teachers to what extent these supported their professional development (on a scale of 1-4). Such perceptions of the impact of collaboration were intended to measure their willingness or commitment to collaborate, which previous research identified as an important personal precondition of collaboration (Vangrieken et al., 2015). In a similar manner regarding teacher learning, Opfer and Pedder argued that the beliefs about learning teachers bring in the guise of values, shaped by past experiences, impact their own decisions about learning (Opfer and Pedder 2011; Opfer et al. 2011).

\section{Individual factors}

As independent demographic variables, we analysed gender, age group, and length of teaching experience.

We included teacher profile (being a general education teacher, a vocational teacher or a trainer) in our analysis as an independent variable. In some of our analysis we also used a version of this variable, teacher type, which distinguishes only general subject and vocational teachers/trainers. Considering the latter only, we also analysed associations with the length of previous vocational work experience and whether they currently work in the vocation taught.

Teacher collaboration is considered to enhance teachers' individual and collective selfefficacy, but low self-efficacy was also found to be a factor hindering collaboration (Vangrieken et al. 2015; Nissilä et al. 2015). We measured self-efficacy by adapting the TALIS 2018 scale, which is based on the multidimensional framework of Tschannen-Moran and Woolfolk Hoy (2001). This framework distinguishes three core factors of teacher self-efficacy: the ability to enact certain teaching behaviour related to classroom management, instruction and student engagement (using a scale of 1-4).

\section{Organisational factors}

Previous research found a reciprocal relationship between collaboration and collegiality as well as significant correlations with other dimensions of school climate and school leadership. We measured general school climate by adapting the TALIS 2018 measure, asking teachers to what extent they agreed with statements about participation among stakeholders, collegiality and teacher-student relations (on a scale of 1 to 5).

We used another instrument as well, borrowed from a previous Hungarian survey, to further assess the nature of collegial relations. We asked teachers to describe their school climate in four dimensions on a scale of 1 to 5 , where 1 and 5 meant the opposite 
characteristics: 'tense'-'relaxed'; 'hardly innovative'-'innovative'; 'small-minded''tolerant'; 'rigid'-'flexible', 'discouraging'-'encouraging' (Baráth 2007).

Transformational leadership was measured by an adaptation of the instrument used in Geijsel et al. (2009), which includes items referring to the dimensions of initiating and identifying a vision, providing individualised consideration and support, and providing intellectual stimulation. We incorporated two more items from Opfer et al. (2011) on supporting external collaborations and Sági (2015) on the availability of professional support from school leaders.

To measure barriers to collaboration, we designed a new question with items referring to mainly structural features that might be relevant in a VET context. These include the high number of part-time instructors, frequent change of staff, or the different nature and time schedule of the different teacher profiles. Teachers had to indicate the extent to which they agreed that these posed a barrier to teacher collaboration in their school, on a Likert scale of 1-4.

\section{Data analysis}

We used descriptive statistics to describe in what forms VET teachers collaborate, how they perceive the impact of these on their professional development, and what posed a barrier to their collaboration with colleagues. In order to analyze associations between collaboration and selected personal and organisational factors, we created indices (new variables) through principal component analyses from the observed variables. We tested statistical significance of differences in collaboration by our selected categorical variables by analysis of variance (one-way ANOVA). Correlations between collaboration and the selected individual and organisational factors were analysed by calculating Pearson correlation coefficients. Statistical analyses were conducted using SPSS version 25.0 software.

\section{Results}

\section{VET teachers' collaborative activities, perceptions of impact and barriers}

Our respondents participate in exchange and sharing-type collaboration activities much more than in deeper professional collaboration (see Fig. 1). While a significant majority said that it was rather or completely typical for them to engage in professional discussions and exchange teaching materials with colleagues, only slightly more than half participate in joint activities (e.g. co-teaching, organising joint projects across different classes/years) and observe colleagues' classes to learn from them. Only a minority typically observe colleagues' classes to give feedback or carry out joint research (such as analysing the performance of the school or studying a new pedagogical theory or method). Significant proportions (12-31\%) of our respondents claimed that it was not at all typical for them to engage in deeper forms of professional collaboration.

VET teachers' perceptions regarding the impact of these collaborative activities on their own professional development closely correspond to their practice of collaboration. As Fig. 2 shows, our respondents believed that exchange-type collaboration activities supported their professional development more than participating in deeper forms of collaboration. Significant shares $(23,22$ and $31 \%$, respectively) believe that engaging 
Engage in discussions with my colleagues about the learning development of specific students. $(n=295)$ Exchange teaching materials with my colleagues. $(n=293)$

Discuss with my colleagues what and how we are learning. $(n=294)$

Engage in joint activities in a class or across different classes and age groups with my colleagues. $(n=293)$ Observe my colleagues' classes to learn from them. $(n=293)$

Observe my colleagues' classes in order to provide feedback. $(n=291)$

Carry out joint research with my colleagues, aimed at improving teaching practice. $(n=292)$



Fig. 1 How typical is it for you to do these activities? (\%)

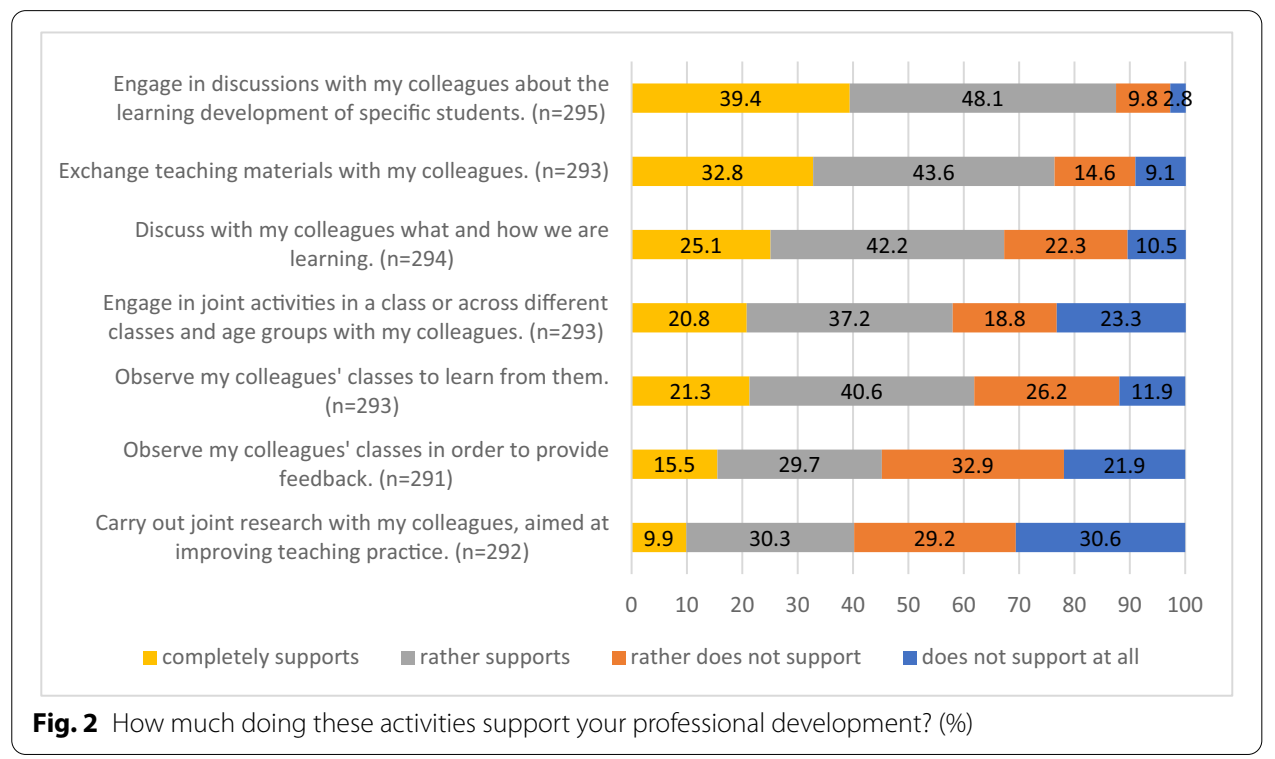

in joint activities, observing colleagues' classes to give feedback, and carrying out join research (analysis) do not at all support their own professional learning.

Nevertheless, the share of respondents who perceived a positive impact of deeper forms of collaboration was higher than the share of those who typically participated in these activities (see Fig. 3). Comparing teachers' mean scores for collaboration practices and perceptions of impact by conducting a paired samples t-test for all respondents (following the example of Pedder and Opfer 2013) showed that the difference was statistically significant for each deeper collaboration activity. However, the effect size of the difference is small, the highest is for observing colleagues' classes to learn from them (see Table 12 in appendix). 
Engage in discussions with my colleagues about the learning development of specific students. $(n=295)$

Exchange teaching materials with my colleagues. $(n=293)$

Discuss with my colleagues what and how we are learning. $(n=294)$

Engage in joint activities in a class or across different classes and age groups with my colleagues. $(n=293)$

Observe my colleagues' classes to learn from them. $(n=293)$

Observe my colleagues' classes in order to provide feedback. $(n=291)$

Carry out joint research with my colleagues, aimed at improving teaching practice. $(n=292)$



participation a perception of impact

Fig. 3 Share of respondents who (very much or rather) typically participate in collaboration activities compared with those who perceive a (very much or rather) positive impact

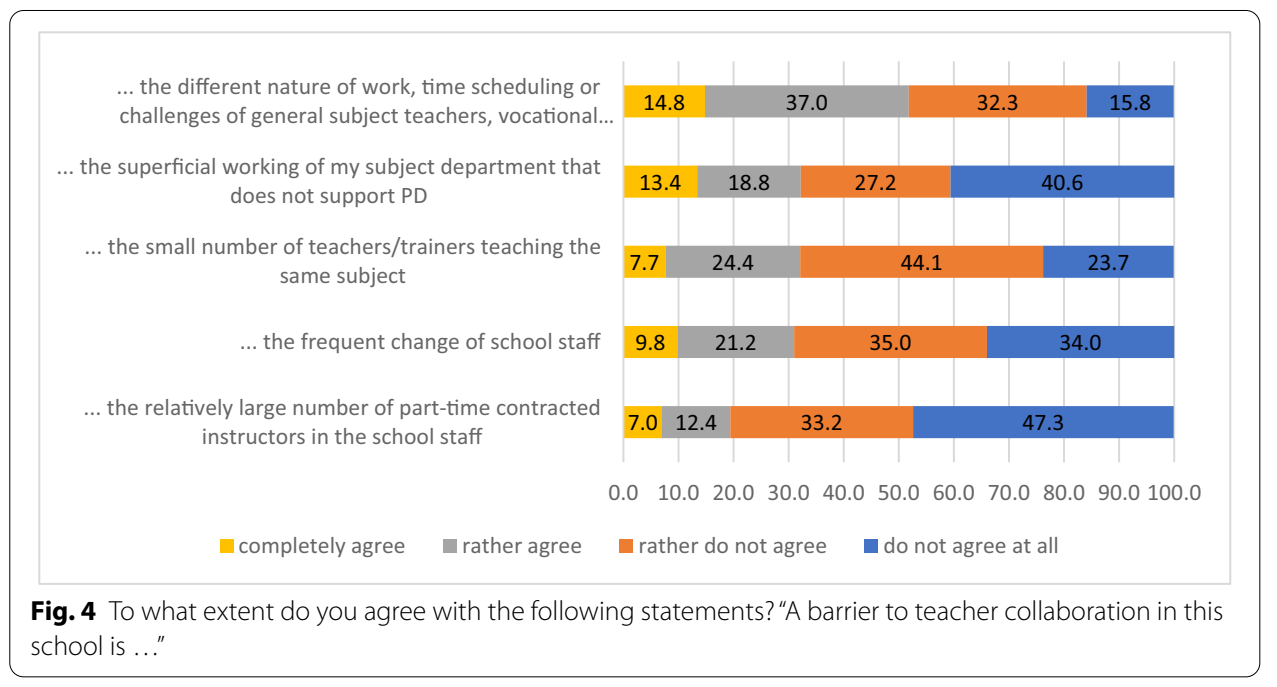

Regarding the barriers to teacher collaboration in a VET context, slightly more than half of our respondents agreed that the different nature of work, time scheduling or challenges of the three teacher profiles was a barrier to their collaboration with colleagues (see Fig. 4). The majority did not find structural features related to school size and human resources, such as frequent change of staff, high share of part-time instructors, and small number of teachers teaching the same subject, as limiting their collaboration with colleagues. A possible explanation for the might be that our sample involved only 11 schools providing VET in different fields, and the presence of such structural features may very much depend on the VET field and school size. Nearly a third of our respondents also thought that the superficial working of their subject department limited teacher collaboration in their school. 
Links between VET teachers' collaboration and our selected individual and organisational factors

For further analysis of our data, we constructed new variables (indices) from our observed (interval) variables through principal component analysis, in order to condense our data while minimizing information loss. Each of the extracted components preserved at least $45 \%$ of the information (variance) embodied by the variables in our original dataset. We extracted components so that stronger factor loadings indicate higher weight of the dimensions measured by the constituting items. We tested reliability by computing Cronbach $\alpha$, which was $>0.7$ in each case.

Three variables (indices) were thus constructed to describe teacher collaboration (see Table 13 in appendix). As regards collaboration practice, items referring to deeper collaboration activities and those referring to sharing (discussion and exchange) constituted two different components: the 'deeper collaboration' index and the 'sharing' index. Regarding perceptions of impact, only one component was extracted, which we named as the 'collaboration perception of impact' index.

To describe potential explanatory factors, we constructed the following variables (see Table 13 in appendix):

- self-efficacy (one component identified after excluding five items);

- school climate (one component identified after excluding two items);

- collegial relations (one component extracted, retaining all five original items);

- transformational leadership (one component extracted, retaining all seven original items).

- barriers to collaboration (one component identified, retaining all five original items);

Next, we examined if our selected individual and organisation variables showed any significant correlations with the two collaboration practice indices and the collaboration perception of impact index.

We first assessed potential differences in collaboration by the selected individual categorical variables conducting one-way ANOVAs. Statistically significant associations with collaboration were found only between gender, age groups and teacher profiles. Considering only vocational teachers and trainers, current work in the original vocation (alongside teaching) could not be associated with any differences in collaboration practices or perceptions of impact.

Statistically significant differences by gender were only found in sharing (see Table 1). Our female repondents participate in exchange and cooperation-type activities more often than their male colleagues. However, effect size was very small $\left(\eta^{2}=0.030\right)$, meaning that gender explains only $3 \%$ of the variance in sharing-type collaboration.

Table 1 Means, standard deviations and one-way analyses of variance in sharing by gender

\begin{tabular}{|c|c|c|c|c|c|c|}
\hline \multirow[t]{2}{*}{ Variable (index) } & \multicolumn{2}{|l|}{ Male } & \multicolumn{2}{|l|}{ Female } & \multirow[t]{2}{*}{$F(1,290)$} & \multirow[t]{2}{*}{$\eta^{2}$} \\
\hline & $M$ & SD & $M$ & SD & & \\
\hline Sharing & -.193 & 1.047 & -.097 & .963 & $5.491^{*}$ & .030 \\
\hline
\end{tabular}


Table 2 Means, standard deviations and one-way analyses of variance in deeper collaboration by teacher profile

\begin{tabular}{|c|c|c|c|c|c|c|c|c|}
\hline \multirow[t]{2}{*}{ Variable (index) } & \multicolumn{2}{|c|}{$\begin{array}{l}\text { General subject } \\
\text { teacher }\end{array}$} & \multicolumn{2}{|c|}{ Vocational teachers } & \multicolumn{2}{|c|}{$\begin{array}{l}\text { Vocational } \\
\text { trainer }\end{array}$} & \multirow[t]{2}{*}{$F(2,282)$} & \multirow[t]{2}{*}{$\eta^{2}$} \\
\hline & $M$ & SD & $M$ & SD & $M$ & SD & & \\
\hline Deeper collaboration & .056 & .954 & -.271 & 1.03 & .290 & 1.00 & $.5370^{*}$ & .030 \\
\hline
\end{tabular}

Table 3 Means, standard deviations and one-way analyses of variance in collaboration perception of impact by teacher profile

\begin{tabular}{|c|c|c|c|c|c|c|c|c|}
\hline \multirow[t]{2}{*}{ Variable (index) } & \multicolumn{2}{|c|}{$\begin{array}{l}\text { General } \\
\text { subject } \\
\text { teacher }\end{array}$} & \multicolumn{2}{|c|}{$\begin{array}{l}\text { Vocational } \\
\text { teachers }\end{array}$} & \multicolumn{2}{|c|}{$\begin{array}{l}\text { Vocational } \\
\text { trainer }\end{array}$} & \multirow[t]{2}{*}{$F(2,270)$} & \multirow[t]{2}{*}{$\eta^{2}$} \\
\hline & M & SD & M & SD & M & SD & & \\
\hline Collaboration perception of impact & .085 & .894 & -.263 & 1.01 & .192 & 1.23 & $4.201^{*}$ & .037 \\
\hline
\end{tabular}

By contrast, we found statistically significant differences by teacher profile in deeper collaboration and perceptions of impact (see Tables 2 and 3). Scheffe post-hoc tests revealed that vocational trainer respondents participate in deeper collaboration more often than vocational teachers. There was no statistically significant difference between vocational trainers' and general subject teachers' participation. Post hoc comparisons using the Games-Howell tests (run due to lack of homogeneity of variances, as shown by the Levine test) showed that vocational teachers perceived a lower impact of collaboration than general subject teachers. No statistically significant difference was found between vocational teachers and trainers in this respect. However, effect sizes were very small in each case $\left(\eta^{2}=0.030\right.$ and 0.037 , respectively).

Regarding age, we found statistically significant differences between younger (-40), middle-aged (40-54) and older (55-) age groups (see Tables 4, 5 and 6). Scheffe posthoc tests revealed that middle-aged VET teachers participate in deeper collaboration more typically than younger teachers, and in sharing-type activities more typically than older teachers. There was no statistically significant difference between younger and older teachers' participation in either type of collaboration. Middle-aged teachers also perceived a higher impact of collaboration compared to older teachers. However, effect sizes were very small in each case.

To analyse associations between collaboration and our selected individual and organizational factors, we calculated Pearson's correlation coefficients. Vocational teachers/trainers' work experience in the vocation taught (length) significantly correlates (weakly) with only the length of teaching experience $(r(125)=0.213, p<0.05)$, but not with collaboration or any other factors. Nearly all our other indicators correlate significantly $(\mathrm{p}=0.000)$, though the strength of correlations (effect sizes) differ. Correlation is strong, and the strongest, between collaboration practices and the perception of impact, while these correlate with the other indicators moderately or weakly (see Table 7). 
Table 4 Means, standard deviations and one-way analyses of variance in sharing by age group

\begin{tabular}{|c|c|c|c|c|c|c|c|c|}
\hline \multirow[t]{2}{*}{ Variable (index) } & \multicolumn{2}{|l|}{-40} & \multicolumn{2}{|c|}{$40-54$} & \multicolumn{2}{|l|}{$55-$} & \multirow[t]{2}{*}{$F(2,289)$} & \multirow[t]{2}{*}{$\eta^{2}$} \\
\hline & $M$ & SD & $M$ & SD & $M$ & SD & & \\
\hline Sharing & -.040 & .960 & .174 & .929 & -.208 & 1.07 & 4.440 & .030 \\
\hline
\end{tabular}

Table 5 Means, standard deviations and one-way analyses of variance in deeper collaboration by age group

\begin{tabular}{|c|c|c|c|c|c|c|c|c|}
\hline \multirow[t]{2}{*}{ Variable (index) } & \multicolumn{2}{|l|}{-40} & \multicolumn{2}{|c|}{$40-54$} & \multicolumn{2}{|l|}{$55-$} & \multirow[t]{2}{*}{$F(2,282)$} & \multirow[t]{2}{*}{$\eta^{2}$} \\
\hline & M & SD & M & SD & M & SD & & \\
\hline Deeper collaboration & -.298 & .950 & .133 & .971 & -.022 & 1.03 & 3.514 & .024 \\
\hline
\end{tabular}

Table 6 Means, standard deviations and one-way analyses of variance in collaboration perception of impact by age group

\begin{tabular}{|c|c|c|c|c|c|c|c|c|}
\hline \multirow[t]{2}{*}{ Variable (index) } & \multicolumn{2}{|l|}{-40} & \multicolumn{2}{|c|}{$40-54$} & \multicolumn{2}{|l|}{$55-$} & \multirow[t]{2}{*}{$F(2,270)$} & \multirow[t]{2}{*}{$\eta^{2}$} \\
\hline & M & SD & M & SD & M & SD & & \\
\hline Collaboration perception of impact & -.136 & .964 & .186 & .924 & -.178 & 1.08 & 4.293 & .031 \\
\hline
\end{tabular}

Collaboration perception of impact shows correlation of nearly the same strength with self-efficacy and all the organisational variables, the strongest with the general school climate. Sharing correlates most with collegial relations. Deeper professional collaboration shows weaker correlations with teacher self-efficacy and all organisational factors, it does not even significantly correlate with the barriers to collaboration. It shows strongest association with transformational leadership. While self-efficacy correlates weakly with each indicator of collaboration, the other individual factor, the length of teaching experience, correlates only with self-efficacy.

The table shows that our explanatory variables correlate significantly with each other as well. The strong correlations between transformational leadership and the two indicators of school climate can be noted here, suggesting that teachers who sense positive school climate and collegial relations, perceive more support from school leaders. Selfefficacy shows only weak correlations with the organisational factors, and none with the barriers to collaboration.

We calculated Pearson correlation coefficients also for the sub-sample of vocational teachers/trainers, involving another variable relevant only for them: length of work experience in the vocation taught. We found that the correlations between collaboration 


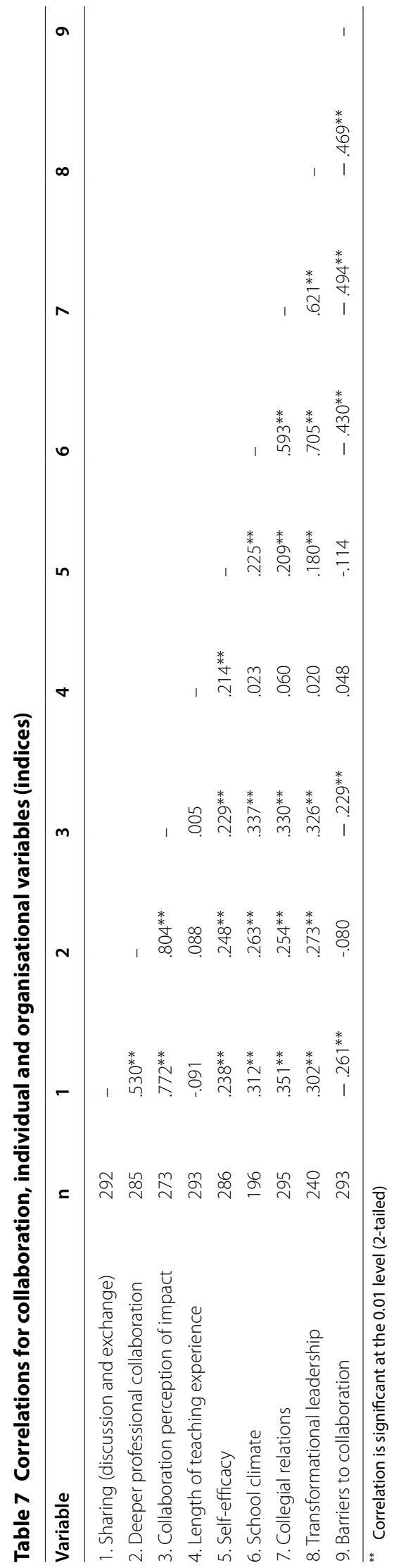




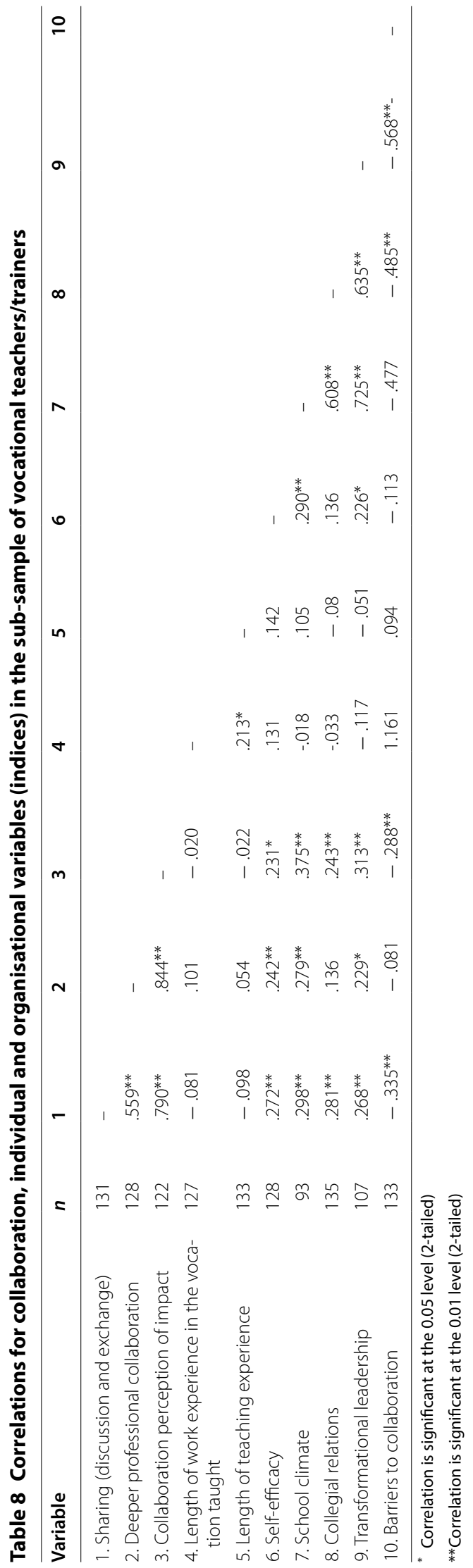


practices and the perception of impact are even stronger (see Table 8). The correlations of collaboration practices with school climate and transformational leadership are, however, weaker. Perception of impact, on the other hand, correlates slightly stronger with all factors but transformational leadership. Vocational teachers/trainers' sharing correlates more strongly with their sense of self-efficacy and perceptions about the barriers to collaboration.

\section{Links between teacher type and our selected individual and organisational factors}

In order to test our hypothesis that due to the different qualifications, professional background and work contexts, profiles of teachers working in Hungarian VET schools might be associated with differences in individual (motivational) and cultural factors that may influence collaboration, we conducted one-way ANOVAs. We did not find any statistically significant differences in these variables by the variable 'teacher profile.' Using another variable called 'teacher type', that makes a distinction between general subject teachers and vocational teachers/trainers, did, however, yield some statistically significant results. General subject teachers sense more relaxed, flexible, tolerant, innovative and encouraging collegial relations in their school, and also more support and encouragement from school leaders, compared to their vocational colleagues. The effect size of both these associations was, however, very small (Tables 9 and 10).

\section{Discussion}

Our data collected among teachers working in Hungarian VET schools mostly confirm and reinforce previous research about teacher collaboration. Regarding the form, our data confirmed distinguishing sharing (professional discussions and exchange) and deeper forms of collaboration that presuppose a higher level of interdependence among teachers. In line with previous TALIS results, we found that sharing is much more

Table 9 Means, standard deviations and one-way analyses of variance in collegial relations by teacher type

\begin{tabular}{|c|c|c|c|c|c|c|}
\hline \multirow[t]{2}{*}{ Variable (index) } & \multicolumn{2}{|c|}{ General subject teacher } & \multicolumn{2}{|c|}{ Vocational teacher/trainer } & \multirow[t]{2}{*}{$F(1,293)$} & \multirow[t]{2}{*}{$\eta^{2}$} \\
\hline & $M$ & SD & $M$ & SD & & \\
\hline Collegial relations & .127 & .973 & -.151 & 1.014 & $5.771^{*}$ & .019 \\
\hline
\end{tabular}

Table 10 Means, standard deviations and one-way analyses of variance in transformational leadership by teacher type

\begin{tabular}{|c|c|c|c|c|c|c|}
\hline \multirow[t]{2}{*}{ Variable (index) } & \multicolumn{2}{|c|}{$\begin{array}{l}\text { General subject } \\
\text { teacher }\end{array}$} & \multicolumn{2}{|c|}{$\begin{array}{l}\text { Vocational teacher/ } \\
\text { trainer }\end{array}$} & \multirow[t]{2}{*}{$F(293)$} & \multirow[t]{2}{*}{$\eta^{2}$} \\
\hline & $M$ & SD & $M$ & SD & & \\
\hline Transformational leadership & .134 & .959 & -.167 & 1.030 & $5.473^{*}$ & .022 \\
\hline
\end{tabular}


prevalent than deeper collaboration also in Hungarian VET schools. Compared with lower secondary teachers in the OECD countries, our VET teacher respondents participate less even in sharing-type activities: while $61 \%$ of the former engaged in discussions about students' learning development, and $47 \%$ exchanged teaching materials at least once a month, only 43 and $29 \%$ of our respondents, respectively, said it was 'completely typical' for them to do these activities (OECD 2020).

Somewhat surprisingly, although the literature often contributes higher benefits to deeper professional collaboration in terms of teachers' professional development (PD), our respondents perceived professional discussions and exchanging teaching materials to be more impactful. Significant shares (20-30\%) claimed that engaging in joint activities, observing colleagues' classes to give feedback or carrying out join research/analysis did not at all support their professional development. This might be explained by a perceived lack of meaningfulness of such joint work and/or a narrow understanding of PD, which has implications for both research and practice. In fact, one limitation of our study is that the instrument we used to measure collaboration focuses on the form of collaboration, whereas the content or agenda also matters and influences what teachers can learn together (Kelchtermans 2006; Levine and Marcus 2010). Concerning the collaboration activity items in our scale, the focus of collaboration is not always evident, and our analysis did not take content into account. As regards practical implications, it would be highly beneficial to expand teachers' conceptions about their own professional development to recognize the value of informal learning and ensure the meaningfulness of joint work, in order to fully realize the learning potential of collaboration. Another implication for practice concerns the slight gap we found between participation in and perceptions of impact of various forms of deeper collaboration. In particular, observing colleagues' classes to learn from them appears to be a more appreciated than practiced activity in VET schools.

Slightly more than half of our respondents agreed that the different nature of work, time scheduling or challenges of the three different teacher profiles working in Hungarian VET schools-general subject teachers, vocational teachers and trainers-was a barrier to their collaboration with colleagues. Our data showed small, but statistically significant differences in collaboration practices and perceptions of impact between these teacher profiles. Our vocational trainer respondents participate most in deeper collaboration activities, while vocational teachers were least likely to participate and perceived the least impact. A possible explanation for this might indeed be the different organisation of their work. Vocational trainers instruct vocational practice in school workshops, which is typically organised in larger blocks of time and in physical proximity with other trainers' workshops. Vocational teachers, however, teach vocational theory in regular (45-min) classes, and often, there is only one teacher teaching certain vocational subjects in the school.

Our hypothesis that differences in VET teachers' collaboration might be related to their different professional background was not confirmed by our data. The length of work experience in the taught vocation did not correlate with any of our dependent 
variables. We found no statistically significant differences between vocational teachers/ trainers who continued working in their original vocation alongside teaching, and those who did not. Furthermore, conducting one-way ANOVAs did not reveal any statistically significant associations between teacher profile and our other independent variables (self-efficacy and the organisational variables) either. We found, however, small, but statistically significant differences in perceptions of collegial relations and transformational leadership between general subject teachers and vocational teachers/trainers. In the sub-sample of the latter, the strength of correlations between collaboration and our independent variables also differed slightly. This suggests that vocational teachers and trainers' collaboration practices might be even more influenced by their perceptions of its impact, and that these perceptions and their sharing practices are more influenced by their perceptions of structural barriers. On the other hand, collegial relations might have less effect on their collaboration. Unfortunately, our small sample size did not allow analysing the influence of the VET field, which might explain differences in department cultures, as suggested by Hoekstra and Pederson (2018).

Regarding further (not VET-specific) individual factors, gender and age group explained small amounts of the variance in VET teachers' collaboration practices and perceptions of impact. Our female respondents participate in sharing-type activities more often than their male colleagues. In contrast with TALIS 2018 findings, we did not find that male teachers tend to engage more often in deeper collaboration (OECD 2020). Our middle-aged (40-55) teacher respondents participate in deeper collaboration more than younger teachers, and in sharing-type activities more than older teachers, and they also perceive a higher impact of collaboration compared to the latter. This finding is line with previous research on teachers' career development, which found that the midcareer of teachers is when energy, commitment, ambition, and self-confidence are at their highest and when teachers refine and diversify their instructional techniques through experimentation (Kyndt et al. 2016), which can be a strong motivator for collaboration. Our data did not confirm the TALIS 2018 finding that teachers with more years of experience tend to collaborate more frequently than teachers of the same age but with fewer years of experience (OECD 2020). The length of teaching experience did not significantly correlate with collaboration in our data.

Among our personal factors, self-efficacy had the strongest correlation with collaboration. While increased self-efficacy can be an outcome of teacher development through collaboration, the relationship might be reciprocal, and it might also be a precondition of collaboration. It can be an important motivational factor of teachers' workplace learning (Geijsel et al. 2009; Thoonen et al. 2011), although low self-efficacy might also impede participation (Vangrieken et al. 2015; Nissilä et al. 2015).

The strongest correlations in our data were found between collaboration practices and perceptions of impact, which we used here as a measure of teachers' willingness to collaborate, resulting from its perceived impact. This confirms the significant role of teachers' beliefs in teacher collaboration and learning (Opfer and Pedder 2011). Our results 
also corroborate the importance of school climate and collegiality for collaboration. VET-specific structural conditions as measured by our 'barriers to collaboration' index seem to influence sharing and perceptions of impact only, they are not significantly associated with our respondents' participation in deeper forms of collaboration. Among our selected organisational variables, transformational leadership correlates most, though only weakly, with deeper collaboration. Our data thus confirm the significant role of school leaders in ensuring the preconditions of collaboration by eliminating structural barriers, promoting good collegial relations and climate, and providing clear goals and sufficient motivation and support for joint work.

Finally, we have to note the limited generalizability of our results due to the relatively small sample size and, more importantly, the fact that our sample involved VET teachers only from one vocational centre located in the capital city of Hungary. In spite of the heterogeneity of its VET programme offer in terms of both VET field and education level, our data are not representative even for Hungarian VET, and some of our results may not at all be relevant for VET systems that differ in some significant structural aspects (such as teacher profiles). Our small sample size did not allow for including school-level variance in the analyses either. Since our models of individual and organisational factors affecting collaboration among VET teachers explain only small to moderate percentage of the variance in collaboration activities and perceptions of impact, future research would be needed to identify and test more relevant factors. This should involve both qualitative explorative studies as well as representative teacher surveys involving a large sample size and new instruments.

\section{Conclusions}

Our study based on a quantitative analysis of data collected in an online teacher survey $(n=303)$ in one vocational centre aimed to explore the forms of teacher collaboration in Hungarian VET schools, and to identify some general and VET-specific factors that may influence it. Our findings show that sharing-type collaboration, that is, professional discussions and exchange of materials are widespread among VET teachers. They are much less likely to participate in deeper collaborative activities that presuppose higher levels of interdependence among teachers, such as joint activities, joint research, or observing colleagues' classes, and they also perceive a smaller impact of these activities. VET teachers' collaboration practices correlate most with their perceptions of their impact. More frequent collaboration and perceptions of higher impact correlate with teachers' higher self-efficacy and relaxed, tolerant and encouraging collegial relationships. Of our organisational factors, collegial relations correlated most strongly with sharing, transformational leadership with deeper collaboration, and the general school climate with perceptions about the impact of collaboration. 
Our findings largely confirm and validate previous research on teacher collaboration in general and lower level educational contexts by providing data on VET teacher collaboration. We also noted the influence of some VET-specific organisational and individual factors. Slightly more than half of our respondents agreed that the different nature of work, time scheduling and challenges of the three teacher profiles working in Hungarian VET schools-general subject teachers, vocational teachers and trainers-was a barrier to their collaboration. We found small, but statistically significant differences in collaboration between these teacher profiles: vocational trainers (who instruct vocational school practice) showed the highest level of participation in deeper collaboration, while vocational teachers were least likely to participate and perceived the least impact. We did not find significant associations between vocational teachers/trainers' collaboration and their prior or current work experience in the taught vocation.

Although the generalizability of our results is limited due to the small sample size and method of sampling, as well as the variability of the wider VET context, our exploratory study may still provide valuable data on VET teacher collaboration and the influencing factors. The findings might contribute to the design of future studies on this under-researched topic.

\section{Abbreviations}

PD: Professional development; SEN: Special education needs; VET: Vocational education and training

\section{Acknowledgements}

Not applicable.

Author contributions

The first author conceived of the study, designed the measuring instruments, collected data, prepared the statistical analyses, and prepared the first draft and processed changes to the manuscript. The second author consulted the study design and statistical analyses, and suggested improvements to the manuscript and its amendment. Both authors read and approved the final manuscript.

\section{Authors' information}

The first author is a PhD student at Eötvös Loránd University (ELTE) Faculty of Education and Psychology, Doctoral School of Education and Institute of Education, Budapest, Hungary. The second author is an associate professor at ELTE and director of the Institute of Education.

Funding

Not applicable.

Availability of data and materials

Collected data saved in SPSS.sav format and the questionnaire in Hungarian are available to members of the scientific community upon request.

\section{Ethics approval and consent to participate}

The study received ethical approval from the Research Ethical Committee of the Faculty of Education and Psychology of ELTE EÖtvös Loránd University (No. 2019/101) prior to the start of research. Informed consent of participants in the online survey had been obtained at the first step of completing the questionnaire.

\section{Competing interests}

The authors declare that they have no competing interests.

\section{Author details}

${ }^{1}$ Doctoral School of Education, Institute of Education, ELTE Eötvös Loránd Tudományegyetem, Budapest, Hungary.

${ }^{2}$ Institute of Education, ELTE Eötvös Loránd Tudományegyetem, Budapest, Hungary. 


\section{Appendix}

See Tables 11, 12, 13.

Table 11 Share of respondents by teacher profile

\begin{tabular}{lccc}
\hline & \multicolumn{2}{c}{ Respondents } & \multicolumn{2}{c}{ Response rate* $^{*}$} \\
\cline { 2 - 4 } & $\boldsymbol{n}$ & $\%$ & $\%$ \\
\hline General subject teacher & 165 & 54.5 & 58.9 \\
Vocational teacher & 88 & 29.0 & 77.9 \\
Vocational trainer & 50 & 16.5 & 31.1 \\
Total & 303 & 100.0 & - \\
\hline
\end{tabular}

Compared to those with an employment contract ( $17 \%$ of all employees, one third of vocational trainers and $17 \%$ of vocational teachers, worked with an assignment contract)

Table 12 Collaboration practices and perceptions of impact: means, standard deviations and significance of difference

\begin{tabular}{|c|c|c|c|c|c|c|c|c|}
\hline & \multicolumn{3}{|c|}{$\begin{array}{l}\text { Collaboration } \\
\text { practice }\end{array}$} & \multicolumn{3}{|c|}{$\begin{array}{l}\text { Perception } \\
\text { of impact }\end{array}$} & \multicolumn{2}{|c|}{ Difference } \\
\hline & $\mathbf{n}$ & M & SD & $\mathbf{n}$ & M & SD & $\mathbf{p}$ & Cohen's d \\
\hline Observe my colleagues'classes to learn from them & 293 & 2.54 & 0.89 & 286 & 2.71 & 0.93 & .000 & 0.32 \\
\hline $\begin{array}{l}\text { Observe my colleagues' classes in order to provide } \\
\text { feedback }\end{array}$ & 291 & 2.32 & 0.96 & 283 & 2.39 & 1.00 & .010 & 0.16 \\
\hline $\begin{array}{l}\text { Engage in joint activities in a class (e.g. co-teaching) or } \\
\text { across different classes and age groups (e.g. organizing } \\
\text { projects) with my colleagues }\end{array}$ & 293 & 2.47 & 1.06 & 288 & 2.56 & 1.06 & .007 & 0.16 \\
\hline Exchange teaching materials with my colleagues & 293 & 2.98 & 0.89 & 287 & 3.00 & 0.92 & .002 & 0.18 \\
\hline $\begin{array}{l}\text { Engage in discussions with my colleagues about the } \\
\text { learning development of specific students }\end{array}$ & 295 & 3.31 & 0.70 & 287 & 3.24 & 0.74 & .600 & 0.03 \\
\hline $\begin{array}{l}\text { Carry out joint research with my colleagues. aimed at } \\
\text { improving teaching practice }\end{array}$ & 292 & 2.12 & 0.94 & 284 & 2.19 & 0.99 & .003 & 0.18 \\
\hline $\begin{array}{l}\text { Discuss with my colleagues what and how we are learn- } \\
\text { ing }\end{array}$ & 294 & 2.82 & 0.90 & 287 & 2.82 & 0.93 & .778 & 0.02 \\
\hline
\end{tabular}


Table 13 Items and component loadings in study variables created by principal component analysis

Deeper collaboration

( $1=$ not at all typical $4=$ completely typical)

(total variance explained: 61.4\%; KMO: .704 Cronbach a: 0.784)

* Original question was: How typical is it for you to do these activities?

\begin{tabular}{lc}
\hline & $\begin{array}{c}\text { Component } \\
\text { loadings }\end{array}$ \\
\hline Observe my colleagues' classes to learn from them & .847 \\
Observe my colleagues' classes in order to provide feedback & .857 \\
$\begin{array}{l}\text { Engage in joint activities in a class (e.g. co-teaching) or across different classes and age groups } \\
\text { (e.g. organizing projects) with my colleagues }\end{array}$ & .692 \\
$\begin{array}{l}\text { Carry out joint research with my colleagues, aimed at improving teaching practice (e.g. analysing } \\
\text { the performance of the school, studying a new pedagogical theory or method) }\end{array}$ & .728 \\
\hline
\end{tabular}

\section{Sharing}

( $1=$ not at all typical; $4=$ completely typical)

(total variance explained: 64.3\%; KMO: .673 Cronbach a: 0.713)

* Original question was: How typical is it for you to do these activities?

Component loadings

Exchange teaching materials with my colleagues

Engage in discussions with my colleagues about the learning development of specific students $\quad .820$

Discuss with my colleagues what and how we are learning

\section{Collaboaration perception of impact}

( $1=$ not at all typical; $4=$ completely typical)

(total variance explained: $47.4,1 \%$; KMO: .804 Cronbach a: 0.813 )

* Original question was: How much do these activities support your professional development?

\begin{tabular}{lc}
\hline & $\begin{array}{c}\text { Component } \\
\text { loadings }\end{array}$ \\
\hline Observe my colleagues' classes to learn from them & .758 \\
Observe my colleagues' classes in order to provide feedback & .757 \\
$\begin{array}{l}\text { Engage in joint activities in a class (e.g. co-teaching) or across different classes and age groups } \\
\text { (e.g. organizing projects) with my colleagues }\end{array}$ & .673 \\
Exchange teaching materials with my colleagues & .711 \\
Engage in discussions with my colleagues about the learning development of specific students & .606 \\
Carry out joint research with my colleagues, aimed at improving teaching practice (e.g. analysing & .629 \\
the performance of the school, studying a new pedagogical theory or method) & .670 \\
\hline Discuss with my colleagues what and how we are learning & \\
\hline
\end{tabular}

\section{Self-efficacy}

( $1=$ not at all typical; $4=$ completely typical)

(proportion of variance explained: $49.9 \%$; KMO: .847 Cronbach a: 0.853 )

* Original question was: In your teaching, to what extent can you do the following?

\begin{tabular}{lc}
\hline & $\begin{array}{c}\text { Component } \\
\text { loadings }\end{array}$ \\
\hline Control disruptive behaviour in the classroom & .759 \\
Motivate students who show low interest in school work & .653 \\
Make my expectations about student behaviour clear & .763 \\
Help students think critically & .632 \\
Get students to follow classroom rules & .713 \\
Calm a student who is disruptive or noisy & .768 \\
Use a variety of assessment strategies & .682 \\
Provide an alternative explanation, for example when students are confused & .665 \\
\hline
\end{tabular}


Table 13 (continued)

\begin{tabular}{|c|c|}
\hline $\begin{array}{l}\text { Collegial relations } \\
(1=\text { not at all typical; } 5=\mathrm{co} \\
\text { (proportion of variance exp } \\
{ }^{*} \text { Original question was: Yol } \\
\text { among the teaching staff in }\end{array}$ & imate \\
\hline & $\begin{array}{l}\text { Component } \\
\text { loadings }\end{array}$ \\
\hline tense_relaxed & .843 \\
\hline less innovative_-innovative & .811 \\
\hline small-minded_tolerant & .892 \\
\hline rigid_flexible & .900 \\
\hline discouraging_encouraging & .903 \\
\hline
\end{tabular}

\section{School climate}

( $1=$ not at all typical; $5=$ completely typical)

(proportion of variance explained: $55.7 \%$; KMO: .885 Cronbach a: 0.864 )

* Original question was: To what extent do you agree with the following statements about your school?

\begin{tabular}{lc}
\hline & $\begin{array}{c}\text { Component } \\
\text { loadings }\end{array}$ \\
\hline School provides staff with opportunities to actively participate in school decisions & .670 \\
In this school there is a collaborative school culture characterised by mutual support. The school & .828 \\
staff share a common set of beliefs about teaching and learning & .797 \\
The school staff share a common set of beliefs about teaching and learning & .668 \\
Teachers and students usually get on well with each other & .693 \\
If a student needs additional support, the school provides it & .807 \\
In this school most teachers/trainers strive to continuously develop their knowledge of teaching & .748 \\
and learning & \\
There is high level collaboration between the school and local employers
\end{tabular}

\section{Transformational leadership}

( $1=$ not at all typical; $4=$ completely typical)

(proportion of variance explained: $73.3 \%$; KMO: .924 Cronbach a: 0.939 )

* Original question was: To what extent do you agree with the following statements about your school?

\begin{tabular}{lc}
\hline & $\begin{array}{c}\text { Component } \\
\text { loadings }\end{array}$ \\
\hline $\begin{array}{l}\text { In this school, teachers can count on getting support and advice from school leaders } \\
\text { School leaders express clear objectives for developing the school and refer explicitly to these dur- } \\
\text { ing the decision-making process }\end{array}$ & .887 \\
$\begin{array}{l}\text { School leaders show appreciation when a teacher takes the initiative to improve her/his teaching } \\
\text { practice or to engage in professional learning activities }\end{array}$ & .875 \\
School leaders create sufficient opportunities for teachers for their professional development & .886 \\
School leaders encourage teachers to seek and discuss new knowledge relevant to developing & .882 \\
the school & .797 \\
School leaders regularly discuss with individual teachers their personal development goals & .806 \\
\hline School leaders support teachers in sharing practice with other schools & \\
\hline
\end{tabular}

\section{Barriers to collaboration}

( $1=$ not at all typical; $4=$ completely typical)

(proportion of variance explained: 52.7\%; KMO: .768 Cronbach a: 0.7739)

* Original question was: To what extent do you agree with the following statements? A barrier to teacher collaboration in this school is ...

Component 
Table 13 (continued)

\section{Barriers to collaboration}

( $1=$ not at all typical; $4=$ completely typical)

(proportion of variance explained: 52.7\%; KMO: .768 Cronbach a: 0.7739 )

* Original question was: To what extent do you agree with the following statements? A barrier to teacher collaboration in this school is ...

Component

loadings

The different nature of work, time scheduling or challenges of general subject teachers, vocational .735

teachers and trainers

The small number of teachers/trainers teaching the same subject

The superficial working of my subject department that does not support PD $\quad .715$

Received: 17 August 2020 Accepted: 24 December 2020

Published online: 13 January 2021

\section{References}

Ainley J, Carstens R (2018) Teaching and Learning International Survey (TALIS) 2018 Conceptual Framework. OECD Working Papers, No. 187. OECD Publishing, Paris. Doi: https://doi.org/10.1787/799337c2-en

Baráth T (2007) Az iskola szervezeti és vezetési jellemzői. Új Pedagógiai Szemle 11:3-16. Retrieved from https://epa.oszk. hu/00000/00035/00118/2007-11-ta-Barath-Iskola.html

Beverborg OAG, Sleegers PJC, Van Veen K (2015) Promoting VET teachers'individual and social learning activities: the empowering and purposeful role of transformational leadership, interdependence, and self-efficacy. Emp Res Vocat Educ Train. https://doi.org/10.1186/s40461-015-0018-4

Billett S (2004) Workplace participatory practices: Conceptualising workplaces as learning environments. J Workplace Learn 16(6):312-324. https://doi.org/10.1108/13665620410550295

Bolam R, McMahon A, Stoll L, Thomas S, Wallace M (2005) Creating and sustaining effective professional learing communities. (Research Rep. No. RR637). Bristol, England: University of Bristol, Department for Education and Skills. Retrieved from http://dera.ioe.ac.uk/5622/1/RR637.pdf

Brouwer P, Westerhuis A, Cox A (2016) Supporting teachers and trainers for successful reforms and quality of vocational education and training: mapping their professional development in the EU - Netherlands. Cedefop ReferNet thematic perspectives series. Retrieved from http://libserver.cedefop.europa.eu/vetelib/2016/ReferNet_NL_TT.pdf

Bükki E (2018) Mesterpedagógus szakmai tanárok szakmai életútjai. Educatio 27(3):498-507. https://doi. org/10.1556/2063.27.2018.3.1

Bükki E (2019) Vocational education and training in Europe: Hungary. Cedefop ReferNet VET in Europe reports 2018. Retrieved from http://libserver.cedefop.europa.eu/vetelib/2019/Vocational_Education_Training_Europe_Hunga ry_2018_Cedefop_ReferNet.pd

Cedefop (2016) Briefing note - Professional development for VET teachers and trainers. Retrieved from http://www.cedef op.europa.eu/files/9112_en.pdf

Cedefop (2017) The changing nature and role of vocational education and training in Europe. Volume 1: conceptions of vocational education and training: an analytical framework. Retrieved from http://www.cedefop.europa.eu/files/ draft_agenda_3.pdf

De Bruijn E (2012) Teaching in innovative vocational education in the Netherlands. Teach Teach Theory Pract 18(6):637653. https://doi.org/10.1080/13540602.2012.746499

Expanzió Humán Tanácsadó Kft (2015) A régió szakképzésében résztvevő pedagógusok kompetencia vizsgálata. Budapest. Retrieved from https://www2.itworx.hu/cgi-bin/itworx/download.cgi?vid=606\&uid=-1\&dokid=480

Fehérvári A (2014) A szakmai képzés és társadalmi átalakulás. Új Mandátum Könyvkiadó, Budapest. Retrieved from https://issuu.com/emesekarsai/docs/fehervari_szakmkepzes

Geijsel FP, Sleegers PJC, Stoel RD, Krüger ML (2009) The effect of teacher psychological and school organizational and leadership factors on teachers' professional learning in Dutch schools. Element School J 109(4):406-427. https:// doi.org/10.1086/593940

Girardet C, Berger JL (2017) Facing student disengagement: Vocational teachers' evolution of their classroom management TT. J Educ Res Online 9(3): 114-140. Retrieved from h urn:nbn:de:0111-pedocs-153041

Goddard YL, Goddard RD, Tschannen-Moran M (2007) A theoretical and empirical investigation of teacher collaboration for school improvement and student achievement in public elementary schools. Teach Coll Rec 109(4): 877-896. Retrieved from https://www.tcrecord.org/Content.asp?Contentld=12871

Hargreaves A (1994) Changing teachers, changing times. Teachers' work and culture in the Postmodern Age. Cassell, London

Hargreaves A, Fullan M (2012) Professional capital: transforming teaching in every school. Teachers College Press, New York, NY

Hoekstra A, Newton P (2017) Departmental leadership for learning in vocational and professional education. Emp Res Vocat Educ Train. https://doi.org/10.1186/s40461-017-0057-0

Hoekstra A, Pederson KS (2018) Workplace conditions affecting instructor professional learning in vocational and professional education. Paper presented at the annual meeting of the American Educational Research Association in New York City, 2018 2(1), pp 1-5. Doi: https://doi.org/10.15439/2019F121 
Hermann Z, Horn D, Tordai D (2016) A 2013. évi szakképzési reform hatása a tanulók kompetenciáira. In: Munkaerőpiaci tükör 2018. Munkaerőpiaci Tükör . Közgazdaság-és Regionális Tudományi Kutatóközpont, Budapest, pp 63-68. Retrieved from http://real.mtak.hu/105269/1/Munkaeropiaci_Tukor_2018_egyben.pdf

Hodkinson H, Hodkinson P (2005) Improving schoolteachers' workplace learning. Res Pap Educ 20(2):109-131. https ://doi.org/10.1080/02671520500077921

Hoekstra A, Korthagen F, Brekelmans M, Beijaard D, Imants J (2009) Experienced teachers' informal workplace learning and perceptions of workplace conditions. J Workplace Learn 21(4):276-298. https://doi.org/10.1108/13665 620910954193

Hoekstra A, Kuntz J, Chaudoir S, Chahal M, Newton P (2015) Vocational educators' professional learning activities and workplace affordances. Retrieved from https://www.researchgate.net/profile/Annemarieke_Hoekstra/publi cation/284041153_Vocational_Educators'_Professional_Learning_Activities_and_Workplace_Affordances/links /564baa2608aeab8ed5e77a20.pdf

Információs és Technológiai Minisztérium (2018). Szakképzés 4.0. A szakképzés és felnőttképzés megújitásának középtávú szakmapolitikai stratégiája, a szakképzési rendszer válasza a negyedik ipari forradalom kihívásaira. Budapest. Retrieved from https://www.nive.hu/index.php?option=com_content\&view=article\&id=1024:szakk epzes-40-strategia\&catid=10:hirek\&ltemid $=166$

Kelchtermans G (2006) Teacher collaboration and collegiality as workplace conditions. Zeitschrift Für Pädagogik 52(2): 220-237. Retrieved from https://www.pedocs.de/volltexte/2011/4454/pdf/ZfPaed_2006_2_Kelchterma ns_Teacher_collaboration_collegiality_D_A.pdf

Köpsén S, Andersson P (2017) Reformation of VET and demands on teachers' subject knowledge-Swedish vocational teachers' recurrent participation in a national CPD initiative. J Educ Work 30(1):69-83. https://doi. org/10.1080/13639080.2015.1119259

Kwakman K (2003) Factors affecting teachers' participation in professional learning activities. Teaching and Teacher Education 19(2):149-170. https://doi.org/10.1016/S0742-051X(02)00101-4

Kyndt E, Gijbels D, Grosemans I, Donche V (2016) Teachers' everyday professional development mapping informal learning activities, antecedents, and learning outcomes. Rev Educ Res 86(4):1111-1150. https://doi.org/10.3102/00346 54315627864

Leana (2011) The missing link in school reform. Stanf Soc Innov Rev 9(4): 34. Retrieved from https://www2.ed.gov/progr ams/slcp/201 1 progdirmtg/mislinkinrfm.pdf

Levine TH, Marcus AS (2010) How the structure and focus of teachers' collaborative activities facilitate and constrain teacher learning. Teach Teach Educ 26(3):389-398. https://doi.org/10.1016/j.tate.2009.03.001

Little JW (1990) the persistence of privacy: autonomy and initiative in teachers? professional relations making sense of science, in collaboration with wested view project. Teach Coll Rec 91:509-536

Lortie D (1975) Schoolteacher: a sociological study. University of Chicago Press, London

Misra PK (2011) Vet teachers in Europe: policies, practices and challenges. JVocat Educ Train 63(1):27-45. https://doi. org/10.1080/13636820.2011.552732

Nissilä SP, Karjalainen A, Koukkari M, Kepanen P (2015) Towards competence-based practices in vocational educationWhat will the process require from teacher education and teacher identities? Center Educ Policy Stud J 5(2): 13-34. Retrieved from https://www.cepsj.si/index.php/cepsj/article/view/140

OECD (2020) TALIS 2018 results (Volume II): teachers and school leaders as valued professionals. TALIS, OECD Publishing, Paris. https://doi.org/10.1787/19cf08df-en

Opfer VD, Pedder DG (2011) Conceptualizing teacher professional learning. Rev Educ Res 81(3):376-407. https://doi. org/10.3102/0034654311413609

Opfer VD, Pedder DG, Lavicza Z (2011) The role of teachers' orientation to learning in professional development and change: a national study of teachers in England. Teach Teach Educ 27(2):443-453. https://doi.org/10.1016/j. tate.2010.09.014

Pedder DG, Opfer VD (2013) Professional learning orientations: Patterns of dissonance and alignment between teachers' values and practices. Res Pap Educ 28(5):539-570. https://doi.org/10.1080/02671522.2012.706632

Reeves PM, Pun WH, Chung KS (2017) Influence of teacher collaboration on job satisfaction and student achievement. Teach Teach Educ 67:227-236. https://doi.org/10.1016/j.tate.2017.06.016

Rosenholtz SJ (1989) Teachers' workplace: the social organization of schools. Longman, New York

Sági, M. (2015) Szakképzésben dolgozó pedagógusok változó környezetben. Szakképzési Szemle 31(1):17-36

Schmidt T (2019) Industry currency and vocational teachers in Australia: what is the impact of contemporary policy and practice on their professional development? Res Post Compuls Educ 24(1):1-19. https://doi.org/10.1080/13596 748.2019 .1584431

Thoonen EE, Sleegers PJC, Oort FJ, Peetsma TTD, Geijsel FP (2011) How to improve teaching practices: the role of teacher motivation, organizational factors, and leadership practices. Educ Admin Q 47(3):496-536. https://doi. org/10.1177/0013161X11400185

Timperley H, Wilson A, Barra H, Fung I (2007) Teacher professional learning and development. Best evidence synthesis iteration. Wellington, New Zealand: Ministry of Education. Retrieved from http://www.ibe.unesco.org/fileadmin/ user_upload/Publications/Educational_Practices/EdPractices_18.pdftalis

Tschannen M, Hoy AW (2001) Teacher efficacy: capturing an elusive construct. Teach Teach Educ 17(7):783-805. https:// doi.org/10.1016/S0742-051X(01)00036-1

Tyler M, Dymock D (2019) Maintaining industry and pedagogical currency in VET: practitioners'voices. Int J Train Res 17(1):4-20. https://doi.org/10.1080/14480220.2019.1602218

Vangrieken, K., Dochy, F., Raes, E., \& Kyndt. E. (2015) Teacher collaboration: a systematic review. Educ Res Rev 15:17-40. https://doi.org/10.1016/j.edurev.2015.04.002

\section{Publisher's Note}

Springer Nature remains neutral with regard to jurisdictional claims in published maps and institutional affiliations. 